\title{
Upaya Menghadapi School Phobia Pada Anak Prasekolah Dengan Melibatkan Peran Orang Tua Dalam Pemberian Pola Asuh Yang Benar Di PAUD - TK Yabunaya Bangsal - Mojokerto
}

\author{
Titiek Idayanti*, Kurnia Indriyanti Purnama Sari, Widya Anggraeni \\ STIKes Dian Husada Mojokerto, Indonesia \\ *ti2k.nurul@gmail.com
}

\begin{abstract}
ABSTRAK
School phobia adalah suatu penolakan sekoah yang dilakukan oleh seorang anak karena adanya tekanan emosi, perasaan takut dan cemas dalam menghadapi sekolah. Banyak factor yang dapat memengaruhi terjadinya school phobia pada anak, yaitu faktor internal yg meliputi kondisi fisik, intelegensi, urutan kelahiran, dan faktor eksternal yang terdiri dari lingkungan sekolah serta pola asuh orang tua.

Kegiatan pengabdian kepada masyarakat yang dilakukan di PAUD-TK Yabunaya Bangsal ini bertujuan untuk memberikan pemahaman dan wawasan kepada orang tua tentang bagaimana cara menghadapi anak usia prasekolah yang mengalami school phobia dengan pola asuh yang benar. Sasaran pada kegiatan ini adalah semua wali murid PAUD-TK Yabunaya Bangsal. Pelaksanaan kegiatan dilakukan di PAUD-TK Yabunaya Bangsal. Pelaksanaan kegiatan dimulai dengan membagikan kuesioner tentang school phobia dan pola asuh yang benar pada anak prasekolah untuk di isi wali murid yang bertujuan untuk mengetahui seberapa besar pengetahuan wali murid tentang school phobia dan pola asuh yang benar pada anak usia prasekolah. Kemudian kegiatan inti dilanjut dengan memberikan materi secara ceramah oleh tim penyuluh. Dibuka sesi tanya jawab di akhir acara. Selanjutnya ada kuesiner evaluasi yang dibagikan kepada wali murid dan di isi yang bertujuan untuk menilai keberhasilan kegiatan yang telah dilaksanakan.
\end{abstract}

Kata Kunci: School Phobia, Peran Orang Tua, Pola Asuh Orang Tua

\section{PENDAHULUAN}

Perilaku penolakan sekolah sering kali dianggap sebagai sesuatu yang sangat menantang selayaknya skenario yang menyakitkan bagi orang tua. Kehadiran anak di kelas sering di anggap hal yang wajar bagi pendidikan kelas, hal itu akan berubah fungsi menjadi suatu masalah apabila penolakan sekolah berakibat suatu pembolosan. Penolakan sekolah atau school refusal mempunyai hambatan dan kesulitan untuk mencari kategorinya. Kejadian seperti ini biasanya bersifat heterogen pada anak yang mengalami masalah dengan pemisahan sosial dan keadaan cemas serta depresi Istilah yang lebih luas, perilaku 


\section{Journal of Community Engagement in Health}

penolakan sekolah, termasuk anak-anak dengan emosional berdasarkan penolakan sekolah diuraikan di atas maupun yang secara tradisional disebut sebagai bolos (Kearney, 2005).

Sebuah penelitian yang dilakukan di Indonesia menunjukkan, sekitar 20,3\% anak-anak berusia 3-5 tahun 19,8\% anak berusia 6-11 tahun mengalami fobia sekolah dan 10,9\% pada jenjang pendidikan yang lebih tinggi (Rahmadi, 2010). Banyak factor yang dapat mempengaruhi seorang anak mengalami school phobia, yaitu ada factor internal yang terdiri dari kondisi fisik anak, intelegensi, dan urutan kelahiran. Sedangkan factor eksternal penyebab terjadinya school phobia pada anak adalah lingkungan sekolah dan pola asuh orang tua. Pola asuh yang salah sangat berpengaruh besar terhadap terjadinya school phobia pada anak. Banyak orang tua yang memaksa anaknya untuk bisa dan mampu ketika anak - anak mereka sudah mulai pergi ke Sekolah. Yang terjadi adalah anak usia prasekolah mereka masih belum waktunya untuk mampu menjadi yang terhebat, melainkan yang harus mereka lakukan adalah bermain sambil belajar. Pendidikan anak usia prasekolah sebagian besar bertujuan untuk mengembangkan motoric halus dan motoric kasar anak, hal ini yang masih belum dipahami oleh banyak orang tua. Dari fenomena yang terjadi dimasyarakat, maka tim penyuluh mempunyai ide untuk melakukan kegiatan pengabdian kepada masyarakat di PAUD-TK Yabunaya dengan cara memberikan penyuluhan tentang upaya orang tua dalam menghadapi school phobia pada anak usia prasekolah dengan melibatkan peran orang tua dalam pemberian pola asuh yang benar.

Kegiatan pengabdian kepada masyarakat yang dilakukan di PAUD-TK Yabunaya Bangsal ini bertujuan untuk memberikan pemahaman dan wawasan kepada orang tua tentang bagaimana cara menghadapi anak usia prasekolah yang mengalami school phobia dengan pola asuh yang benar. Sasaran pada kegiatan ini adalah semua wali murid PAUDTK Yabunaya Bangsal. Pelaksanaan kegiatan dilakukan di PAUD-TK Yabunaya Bangsal. Pelaksanaan kegiatan dimulai dengan membagikan kuesioner tentang school phobia dan pola asuh yang benar pada anak prasekolah untuk di isi wali murid yang bertujuan untuk mengetahui seberapa besar pengetahuan wali murid tentang school phobia dan pola asuh yang benar pada anak usia prasekolah. Kemudian kegiatan inti dilanjut dengan memberikan materi secara ceramah oleh tim penyuluh. Dibuka sesi tanya jawab di akhir acara. Selanjutnya ada kuesiner evaluasi yang dibagikan kepada wali murid dan di isi yang bertujuan untuk menilai keberhasilan kegiatan yang telah dilaksanakan. Kemudian tim penyuluh meminta data anak-anak yang mengalami school phobia kepada pihak sekolah, dan melibatkan orang tua agar dapat mengatasi school phobia pada anaknya. Tim akan mengevaluasi kembali setelah dua minggu. Apakah perubahan pola asuh dan peran orang tua berhasil dalam menangani school phobia pada anak. Setelah dua minggu tim penyuluh datang kembali kesekolah dan melakukan evaluasi akhir.

Keberhasilan dari kegiatan ini diharapkan wali murid yang memiliki anak dengan school phobia dapat menerapkan trik - trik dalam menghadapi anak dengan school phobia sesuai dengan penjelasan tim penyuluh, serta orang tua dapat merubah cara pandang tentang pola asuh yang benar dan seharusnya dilakukan pada anak prasekolah. Sehingga anak bersedia untuk sekolah kembali.

\section{METODE}

1. Survey lapangan

Survey lapangan bertujuan untuk mengamati situasi dan keadaan siswa siswi dan wali murid PAUD-TK Yabunaya Bangsal yang direncakan sebagai objek sasaran.

2. Menetukan sasaran 


\section{Journal of Community Engagement in Health}

http://jceh.org

ISSN: 2620-3758 (print); 2620-3766 (online)

https://doi.org/10.30994/jceh.v3i2.61

Vol.3 No.2. Sep 2020. Page.180-183

Sasaran kegiatan pengabdian kepada masyarakat ini adalah semua wali murid PAUDTK Yabunaya Bangsal - Mojokerto

3. Koordinasi

Berkoordinasi dengan pihak pihak sekolah yaitu Ibu Kepala Sekolah untuk menentukan kesepakatan mufakad tentang kapan waktu dan tempat dilakukan kegiatan penyuluhan.

4. Sosialisai kegiatan

Sosialisasi kegiatan bertujuan untuk memberikan informasi kepada wali murid tentang waktu dan tempat pelaksanaan kegiatan.

5. Pelaksanaan kegiatan

Kegiatan dilakukan di PAUD-TK Yabunaya Bangsal Mojokerto. Peserta kegiatan pengabdian kepada masyarakat ini adalah semua wali murid PAUD-TK Yabunaya Bangsal Mojokerto. Sebelum kegiatan dimulai tim penyuluh membagikan kuesioner tentang pola asuh orang tua pada anak usia prsekolah dan school phobia untuk di isi oleh para peserta PKM. Hal ini bertujuan untuk mengetahui seberapa besar pengetahuan orang tua tentang pola asuh yang benar pada anak usia prasekolah dan school phobia. Kegiatan di mulai dengan memberikan penjelasan dan wawasan tentang pola asuh yang benar pada anak usia prasekolah, kemudian dilanjut dengan materi school phobia dan peran orang tua dalam menghadapi school phobia pada anak usia prasekolah. Setelah tim penyuluh selesai memberikan materi, dibuka sesi tanya jawab bagi peserta yang masih belum paham tentang materi yang disampaikan oleh tim penyuluh. Setelah sesi tanya jawab selesai tim penyuluh memberikan kuesioner evaluasi yang bertujuan untuk mengetahui tingkat pemahaman wali murid terhadap materi yang telah disampaikan. Kemudian tim penyuluh meminta data anak-anak yang mengalami school phobia kepada pihak sekolah, dan melibatkan orang tua agar dapat mengatasi school phobia pada anaknya. Tim akan mengevaluasi kembali setelah dua minggu. Apakah perubahan pola asuh dan peran orang tua berhasil dalam menangani school phobia pada anak. Setelah dua minggu tim penyuluh datang kembali kesekolah dan melakukan evaluasi akhir.

\section{HASIL}

Dari kegiatan pengabdian kepada masyarakat diperoleh hasil, untuk kuesioner yang dibagikan sebelum kegiatan dimulai, terdapat 34 (61.8\%) wali murid dari total 55 wali murid yang kurang mengerti dan paham tentang pola asuh yang benar pada anak usia prasekolah dan school phobia. Sedangkan kuesioner yang dibagikan diakhir kegiatan, didapatkan hamper $100 \%$ wali murid sudah dapat memahami dan mengerti tentang pola asuh dan peran orang tua dalam menghadapi school phobia pada anak usia prasekolah.

Evaluasi akhir yang dilakukan dua minggu setelah kegiatan selesai, didapatkan hampir 100\% semua anak yang mengalami school phobia dapat teratasi, anak - anak tersebut sudah mau ke sekolah tanpa didampingi oleh orang tuanya.

\section{PEMBAHASAN}

Dari hasil evaluasi pre kegiatan memeang diperoleh bahwa masih banyak ibu - ibu yang belum paham dan mengerti tentang pola asuh yang benar pada anak usia prasekolah serta peran orang tua dalam menghadapi school phobia.

Teori yang diungkapkan oleh Skinner bahwa anak akan mengalami perubahan apabila adanya dorongan yang memulainya (BF.Skinner, 1935). mendapatkan hasil yang sempurna pada perkembangan mental anak. Teori dari Hurlock mengenai hubungan peran orangtua dengan anak, peran keluarga terutama orangtua sangatlah penting bagi proses pertumbuhan 


\section{Journal of Community Engagement in Health}

jatidiri dan mental anak, suasana gembira dan bahagia di rumah sehingga anak akan belajar serta berusaha untuk mempertahankan kondisi seperti itu (Hurlock, 2003).

Pengabdian kepada masyarakat ini dilakukan untuk memberikan pengetahuan dan wawasan kepada wali murid agar mengetahui pola asuh yang benar pada anak usia prasekolah sehingga dapat mencegah terjadinya school phobia serta dapat memahami perannya sebagai orang tua dalam menghadapi anak yang mengalami school phobia. Dalam kegiatan ini dilakukan penyuluhan dan memberikan materi tentang pola asuh yang benar pada anak usia prasekolah, tentang school phobia dan peran orang tua dalam menghadapi anak dengan school phobia. Sebelum acara di mulai wali murid diberi kuesioner yang harus di isi guna untuk mengukur dan mengetahui seberapa paham wali murid tentang peran dan pola asuh dalam menghadapi school phobia. Kemudia di akhir acara kegiatan wali murid juga diberi kuesioner kembali untuk mengukur keberhasilan kegiatan, materi yang disampaikan dapat dipahami ataukah tidak. Setelah itu tim penyuluh bekerjasama dengan pihak sekolah, dilakukan evaluasi dua minggu setelah kegiatan, bagi anak - anak yang mengalami school phobia dengan melibatkan peran orang tua ternya didapatkan hasi hampir 100\% anak-anak tersebut mau sekolah kembali tanpa didampingi oleh orang tuanya.

\section{KESIMPULAN}

Keberhasilan dari kegiatan pengabdian kepada masyarakat ini, diharapkan semua wali murid dapat merubah cara pandng dan pola asuh yang selama ini kurang tepat terhadap anakny yang masih berusia prasekolah dengan pola asuh yang tepat dan benar untuk anak usia prasekolah, wali murid dapat memahami tentang perannya dalam menghadapi anak yang mengalami school phobia. Sehingga anak-anak yang mengalami school phobia bersedia kembali untuk pergi ke sekolah setiap hari tanpa didampingi oleh orang tua selama disekolah.

\section{UCAPAN TERIMA KASIH}

Ucapan terima kasih kami sampaikan kepada seluruh civitas PAUD-TK Yabunaya Bangsal - Mojokerto yaitu kepada Ibu Kepala Sekolah, segenap dewan guru yang membantu selama proes kegiatan berlangsung, para wali murid yang bersedia meluangkan waktunya untuk hadir dan mengikuti kegiatan sampai selesai.

\section{DAFTAR PUSTAKA}

Antu, Ningsi. Peran Orang Tua dalam Membangun Komunikasi dengan Guru pada Aktivitas Anak di Kelompok B TK Nusa Indah Kabupaten Gorontalo Utara. Skripsi. Universitas Negeri Gorontalo, 2013.

Adiyanti. (2006). Menyiapkan hari pertama sekolah. Yogyakarta : Kanisius.

Ampuni, S. \& Andayani, B. Memahami Anak Dan Remaja Dengan Kasus Mogok Sekolah. Jurnal Psikologi Fakultas Psikologi Universitas Gadjah Mada Volume 34, No. $1,55-75$

Armaliani, R. Fobia sekolah pada anak sekolah dasar. Jurnal psikologi Universitas Gunadarma, volume 1.

Arjana, B. (2006). Memberanikan anak pergi sekolah. Jakarta : Puspa Swara

Astuti, D. (2006). Psikologi anak. Jakarta : Ghalia Indonesia.

Cangara, Hafied. 2006. Pengantar Ilmu Komunikasi. Jakarta: Raja Grafindo Persada 